\title{
The biochemical aftermath of anti-amyloid immunotherapy
}

\author{
Chera L Maarouf ${ }^{1}$, lan D Daugs ${ }^{1}$, Tyler A Kokjohnn ${ }^{1,2}$, Walter M Kalback ${ }^{1}$, R Lyle Patton', Dean C Luehrs',

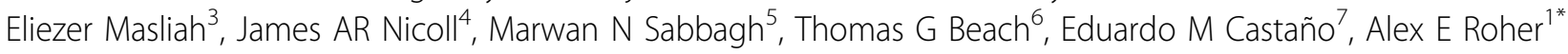

\begin{abstract}
Background: Active and passive immunotherapy in both amyloid-beta precursor protein (APP) transgenic mice and Alzheimer's Disease (AD) patients have resulted in remarkable reductions in amyloid plaque accumulation, although the degree of amyloid regression has been highly variable. Nine individuals with a clinical diagnosis of AD dementia were actively immunized with the A $\beta$ peptide 1-42 (AN-1792) and subjected to detailed postmortem biochemical analyses. These patients were compared to 6 non-immunized AD cases and 5 non-demented control (NDC) cases.

Results: All patients were assessed for the presence of AD pathology including amyloid plaques, neurofibrillary tangles and vascular amyloidosis. This effort revealed that two immunotherapy recipients had dementia as a consequence of diseases other than AD. Direct neuropathological examination consistently demonstrated small to extensive areas in which amyloid plaques apparently were disrupted. Characterization of $A \beta$ species remnants by ELISA suggested that total $A \beta$ levels may have been reduced, although because the amounts of $A \beta$ peptides among treated individuals were extremely variable, those data must be regarded as tentative. Chromatographic analysis and Western blots revealed abundant dimeric A $\beta$ peptides. SELDI-TOF mass spectrometry demonstrated a substantive number of A $\beta$-related peptides, some of them with elongated C-terminal sequences. Pro-inflammatory TNF- $\alpha$ levels were significantly increased in the gray matter of immunized AD cases compared to the NDC and non-immunized AD groups.
\end{abstract}

Conclusions: Immunotherapy responses were characterized by extreme variability. Considering the broad range of biological variation that characterizes aging and complicates the recognition of reliable AD biomarkers, such disparities will make the interpretation of outcomes derived from epidemiologic and therapeutic investigations challenging. Although in some cases the apparent removal of amyloid plaques by AN-1792 was impressive, proportionate alterations in the clinical progression of $A D$ were not evident. The fact that plaque elimination did not alter the trajectory of decline into dementia suggests the likelihood that these deposits alone are not the underlying cause of dementia.

\section{Background}

Alzheimer's disease (AD) dementia affects over 26 million elderly individuals worldwide with this number projected to quadruple by 2050 [1]. In the USA alone, 5.3 million people are afflicted with $\mathrm{AD}$ at an estimated annual cost of $\$ 172$ billion [2]. Given these alarming epidemiological data, devising strategies and therapeutic

\footnotetext{
* Correspondence: alex.roher@bannerhealth.com

'The Longtine Center for Neurodegenerative Biochemistry, Banner Sun Health Research Institute, Sun City, AZ, USA Full list of author information is available at the end of the article
}

interventions to prevent, mitigate or delay the age of onset of this dementia is urgent.

The deposition of amyloid-beta $(\mathrm{A} \beta)$ peptides in the brains of patients with $\mathrm{AD}$ has been a principal focus of intense research since the seminal publications of Glenner and Wong [3] and Masters et al. [4]. The observation of profuse accumulation of parenchymal and vascular $A \beta$ peptides in $A D$ brains was integrated into the amyloid cascade hypothesis as the central causative factor in the pathogenesis of AD dementia [5,6]. Genetic and biochemical studies of amyloid-beta precursor protein (APP), presenilin (PS) 1 and PS2 mutations, all of
C Biomed Central 
which enhance amyloid deposition, strongly support this hypothesis. For many AD researchers, the amyloid hypothesis has attained a status of virtual dogma. However, there are dissidents who have critically questioned this powerful tenet $[7,8]$.

The APP and A $\beta$ peptides are evolutionarily conserved molecules with multiple functions. It has been suggested that $A \beta$ may serve a neurogenic function in the development of neural stem cells [9]. It has also been postulated that $\mathrm{A} \beta$ binds neurotoxic substances and that amyloidosis stimulates their phagocytic removal, thus representing a physiological response to injury $[10,11]$. A decline in $\beta$ - and $\gamma$-secretase activities decreases $A \beta$ production, inducing neuronal death [12]. The $A \beta$ peptides are powerful modulators of microglial activation $[13,14]$, have vasoconstrictor activity [15] that may have a protective role in neuroinflammation and inhibit angiogenesis [16]. A hemostatic function for the $A \beta$ deposited in the walls of the cerebral microvasculature has also been postulated $[17,18]$.

Transgenic ( $\mathrm{Tg}$ ) mouse models have been engineered to express well-characterized APP, PS and tau mutations. These mice are widely utilized to test the efficacy of various compounds and strategies intended to alleviate the deleterious effects of $A \beta$ peptide accumulation or promote its specific clearance. Special attention has been devoted to amyloid peptide immunization therapies to determine their effects on pathology and cognition. Both active and passive immunotherapy in $\mathrm{Tg}$ mice successfully reduced amyloid plaque accumulation and cognition deficits (reviewed in reference [19]). Unfortunately, these promising interventions have yet to produce unequivocal therapeutic benefit in human clinical trials. Several factors may explain discrepancies between $\mathrm{Tg}$ animal and human $\mathrm{AD}$ patient responses to amyloid immunotherapy. Transcriptome analyses have revealed that the murine response to aging is very different from that of humans [20]. In addition, differences in lifespan, intrinsic rates of aging, the relative simplicity of mouse brains and the nature of the induced lesions artificially imposed upon the mice models, may also account for these differences [21-23].

Multiple clinical and pathological observations, in demented individuals, including the biochemical composition of amyloid plaques, suggest that the pathogenesis of $\mathrm{AD}$ is a complex and multifactorial process involving more than $A \beta$. In support of these tenets are the neuropathological, biochemical and immunochemical studies performed on the brains of $\mathrm{A} \beta$-immunized individuals. Although there were obvious extensive areas in which amyloid plaques were absent, the amount of vascular amyloid and soluble $A \beta$ apparently increased while neurofibrillary tangles (NFT) were unaffected [24-31]. More importantly, despite anti-A $\beta$ immunization during a period of mild to moderate cognitive impairment, all patients exhibited continued, progressive dementia and eventually died with AD [29]. Furthermore, A $\beta$ immunotherapy clinical trials have been fraught with frustrations. The AN-1792 clinical trial was halted after $6 \%$ of the immunized population developed aseptic meningoencephalitis [32]. More recently, the Bapineuzumab passive immunotherapy clinical trial was complicated by the development of brain vasogenic edema in some individuals carrying the apolipoprotein (ApoE) $\varepsilon 4$ allele, which compelled the elimination of these subjects from the trial [33]. Notwithstanding these adverse events, recent analyses of AD AN-1792 immunized individuals revealed an apparent reduction in neurite and tau pathology [34,35].

In this paper, we report the neuropathological and biochemical changes observed in a cohort of 9 individuals clinically diagnosed with $\mathrm{AD}$ that were actively immunized with fibrillar $A \beta 1-42$ under the label of AN1792. We compare the present results with our previous investigations of 2 AN-1792 immunized cases [28], and with data derived from 6 untreated AD cases and 5 non-demented control (NDC) individuals.

\section{Methods}

\section{Human Subjects}

The study involved 9 individuals clinically diagnosed with $\mathrm{AD}$ who were actively immunized with the $\mathrm{A} \beta$ peptide 1-42 (AN-1792). Six of these cases were provided by Dr. J. Nicoll, University of Southampton School of Medicine (USSM) and 3 by Dr. E. Masliah, University of California San Diego (UCSD) (Table 1). For comparison, 6 non-immunized AD cases and 5 NDC cases were provided by Dr. T. Beach, Banner Sun Health Research Institute (BSHRI). In the immunized group $(n=9)$, the mean patient age of death was 81 years, 2 were female and 7 were male with a mean disease duration of 8 years. In the NDC individuals, cases \# 1-5, the mean age of death was 82 years ( 2 females and 3 males), and in the AD group, cases \# 6-11, the mean age of death was 82 years ( 5 females and 1 male) with a mean disease duration of 9 years. Their individual ages, gender, ApoE genotype, disease duration, and when applicable, immunogen doses, number of injections and antibody titers as well as the survival time after the application of the first immunization doses are given in Table 1. Of the 9 immunized individuals with a clinical diagnosis of $\mathrm{AD}$, upon postmortem examination, two cases were classified as non-AD dementia cases (\# 21 from USSM and \# 22 from UCSD), having the neuropathological diagnoses of progressive supranuclear palsy (PSP) and hippocampal sclerosis (HS) with severe frontal lobe atrophy, respectively. One case (\# 19) was neuropathologically diagnosed as a Lewy body variant of AD. 
Table 1 Clinical characteristics and immunization details of study subjects

\begin{tabular}{|c|c|c|c|c|c|c|c|c|}
\hline Case ID & $\begin{array}{l}\text { Expired age } \\
\text { (years) }\end{array}$ & Gender & $\begin{array}{l}\text { ApoE } \\
\text { genotype }\end{array}$ & $\begin{array}{l}\text { Disease } \\
\text { Duration (years) }\end{array}$ & $\begin{array}{l}\text { Imm. } \\
\text { Dose }(\mu \mathrm{g})\end{array}$ & $\begin{array}{l}\text { \# of } \\
\text { injections }\end{array}$ & $\begin{array}{l}\text { Mean antibody response } \\
\text { (ELISA units) }\end{array}$ & $\begin{array}{l}\text { PIST } \\
\text { (months) }\end{array}$ \\
\hline \multicolumn{9}{|l|}{ NDC } \\
\hline 1-BSHRI & 77 & $\mathrm{~F}$ & $2 / 3$ & - & - & - & - & - \\
\hline 2-BSHRI & 81 & $\mathrm{~F}$ & $4 / 4$ & - & - & - & - & - \\
\hline 3-BSHRI & 83 & M & $3 / 4$ & - & - & - & - & - \\
\hline 4-BSHRI & 88 & M & $2 / 3$ & - & - & - & - & - \\
\hline 5-BSHRI & 81 & M & $3 / 3$ & - & - & - & - & - \\
\hline Mean & 82 & & & & & & & \\
\hline \multicolumn{9}{|l|}{$A D$} \\
\hline 6-BSHRI & 76 & $\mathrm{~F}$ & $4 / 4$ & 6 & - & - & - & - \\
\hline 7-BSHRI & 82 & M & $3 / 4$ & 7 & - & - & - & - \\
\hline 8-BSHRI & 86 & $\mathrm{~F}$ & $3 / 4$ & 5 & - & - & - & - \\
\hline 9-BSHRI & 80 & $\mathrm{~F}$ & $3 / 3$ & 12 & - & - & - & - \\
\hline 10-BSHRI & 85 & $\mathrm{~F}$ & $3 / 3$ & 9 & - & - & - & - \\
\hline 11-BSHRI & 81 & $\mathrm{~F}$ & $4 / 4$ & 15 & - & - & - & - \\
\hline Mean & 82 & & & 9 & & & & \\
\hline \multicolumn{9}{|c|}{ Immunized $A D^{*}$} \\
\hline 12-USSM & 71 & $\mathrm{~F}$ & $3 / 4$ & 10 & 225 & 8 & $1: 4072$ & 44 \\
\hline 13-USSM & 81 & M & $\mathrm{n} / \mathrm{a}$ & 7 & 50 & 8 & $1: 1707$ & 57 \\
\hline 14-USSM & 82 & M & $3 / 4$ & 6 & 50 & 8 & $1: 4374$ & 60 \\
\hline 15-USSM & 81 & M & $4 / 4$ & 11 & 225 & 7 & $1: 491$ & 63 \\
\hline 16-USSM & 88 & $\mathrm{~F}$ & $3 / 3$ & 11 & 50 & 7 & $1: 137$ & 86 \\
\hline 19-UCSD & 78 & M & $3 / 4$ & 5 & 50 & 1 & $\mathrm{n} / \mathrm{a}$ & 36 \\
\hline 20-UCSD & 86 & M & $3 / 4$ & 9 & 50 & 1 & $\mathrm{n} / \mathrm{a}$ & 60 \\
\hline Mean & 81 & & & 8 & & 6 & & 58 \\
\hline \multicolumn{9}{|c|}{ Immunized non-ADD* } \\
\hline $\begin{array}{l}\text { 21-USSM } \\
\text { PSP }\end{array}$ & 79 & M & $2 / 3$ & 6 & 50 & 8 & $<1: 100$ & 51 \\
\hline $\begin{array}{l}22-U C S D \\
\text { HS }\end{array}$ & 80 & M & $3 / 3$ & 5 & 50 & 1 & $\mathrm{n} / \mathrm{a}$ & 48 \\
\hline
\end{tabular}

NDC, non-demented control; AD, Alzheimer's disease; non-ADD, non-Alzheimer's disease dementias; ApoE, apolipoprotein E; Imm., immunization; PIST, postimmunization survival time; F, female; M, male; BSHRI, Banner Sun Health Research Institute; USSM, University of Southampton School of Medicine; USCD, University of California San Diego; n/a, not available; PSP, progressive supranuclear palsy; HS, hippocampal sclerosis.

* Immunization data for USSM cases taken from Holmes, et al [29], Boche, et al [30] and Boche, et al [35].

\section{Morphological assessments}

The BSHRI AD and NDC cases were assessed for total plaque score, plaque density, total NFT score, Consortium to Establish a Registry for Alzheimer's disease (CERAD), neuritic plaque score, Braak stage, total WMR and total CAA score (see Table 2). Detailed evaluations of these neuropathological parameters are given in a previous publication [36]. Semi-quantitative appraisal of plaque clearance, subjectively attributed to immunotherapy, was estimated as none $(0)$, mild $(+)$, moderate $(++)$ and extensive $(+++)$. The evaluation of CAA content in the UCSD cases was performed by lysing 10 cubes of cerebral cortex tissue ( $1 \mathrm{~cm}$ per side) in $100 \mathrm{ml} 10 \%$ SDS, $10 \mathrm{mM}$ Tris- $\mathrm{HCl} \mathrm{pH} \mathrm{7.4.} \mathrm{After} 48 \mathrm{~h}$ of continuous stirring at room temperature the only remaining structures were the tufts of insoluble blood vessels and attached amyloid deposits. After removal of the detergent, the vessels were air dried on glass slides and stained with thioflavine-S [17].

Clinical, neuropathological and long-term effects of A 342 immunization for the AD patients \# 12-15, originating from USSM, have been thoroughly described elsewhere $[29,30,35]$. The neuropathology reports for cases \# 19, 20 and 22 from UCSD are summarized in Table 3.

\section{Quantification of soluble and insoluble $A \beta$ by ELISA}

All steps were performed at $4^{\circ} \mathrm{C}$. Gray matter tissue (100 $\mathrm{mg}$ ) was homogenized with a Teflon tissue grinder in 6 volumes of $20 \mathrm{mM}$ Tris- $\mathrm{HCl}, 5 \mathrm{mM}$ EDTA, $\mathrm{pH} 7.8$ with protease inhibitor cocktail (PIC, Roche Diagnostics, 
Table 2 Neuropathology of study subjects

\begin{tabular}{|c|c|c|c|c|c|c|c|c|c|c|}
\hline Case ID & $\begin{array}{l}\text { Aß42 } \\
\text { load (\%) }\end{array}$ & Plaque clearance & $\begin{array}{l}\text { Brain } \\
\text { weight }(g)\end{array}$ & $\begin{array}{l}\text { Total WMR } \\
\text { score }\end{array}$ & $\begin{array}{l}\text { Total plaque } \\
\text { score }\end{array}$ & $\begin{array}{l}\text { Plaque } \\
\text { density }\end{array}$ & $\begin{array}{l}\text { Total NFT } \\
\text { score }\end{array}$ & $\begin{array}{l}\text { Cerad } \\
\text { NP }\end{array}$ & $\begin{array}{l}\text { Braak } \\
\text { stage }\end{array}$ & $\begin{array}{l}\text { Total CAA } \\
\text { score }\end{array}$ \\
\hline \multicolumn{11}{|l|}{$\overline{N D C}$} \\
\hline 1 & - & - & 950 & $\mathrm{n} / \mathrm{a}$ & 6.0 & zero & 2.0 & not $A D$ & । & $\mathrm{n} / \mathrm{a}$ \\
\hline 2 & - & - & 1275 & 0 & 7.6 & sparse & 3.0 & not $A D$ & $\|$ & 2 \\
\hline 3 & - & - & 1385 & 0 & 1.0 & zero & 1.0 & not $A D$ & । & 0 \\
\hline 4 & - & - & 1260 & 4 & 6.8 & moderate & 4.3 & $\begin{array}{l}\text { possible } \\
\mathrm{AD}\end{array}$ & III & 3 \\
\hline 5 & - & - & 1190 & 0 & 12.5 & sparse & 6.4 & not AD & III & 5 \\
\hline \multicolumn{11}{|l|}{$A D$} \\
\hline 6 & - & - & 1100 & 0 & 13.5 & moderate & 8.8 & $\begin{array}{l}\text { probable } \\
A D\end{array}$ & IV & 4 \\
\hline 7 & - & - & 1145 & 0 & 13 & frequent & 13 & $\begin{array}{l}\text { definite } \\
A D\end{array}$ & V & 5 \\
\hline 8 & - & - & 1055 & $\mathrm{n} / \mathrm{a}$ & 13.25 & frequent & 8.75 & $\begin{array}{l}\text { definite } \\
A D\end{array}$ & V & 4 \\
\hline 9 & - & - & 765 & 9 & 12.5 & frequent & 14.5 & $\begin{array}{l}\text { definite } \\
A D\end{array}$ & $\mathrm{Vl}$ & 1 \\
\hline 10 & - & - & 960 & 0 & 12.25 & frequent & 12 & $\begin{array}{l}\text { definite } \\
A D\end{array}$ & V & 0 \\
\hline 11 & - & - & 970 & 10 & 13.25 & frequent & 15 & $\begin{array}{l}\text { definite } \\
A D\end{array}$ & $\mathrm{Vl}$ & 10 \\
\hline \multicolumn{11}{|c|}{ Immunized $A D^{*}$} \\
\hline 12 & 4.68 & + & $\mathrm{n} / \mathrm{a}$ & $\mathrm{n} / \mathrm{a}$ & $\mathrm{n} / \mathrm{a}$ & $\mathrm{n} / \mathrm{a}$ & $\mathrm{n} / \mathrm{a}$ & $\mathrm{n} / \mathrm{a}$ & $\mathrm{Vl}$ & $\mathrm{n} / \mathrm{a}$ \\
\hline 13 & 3.32 & ++ & 1120 & $\mathrm{n} / \mathrm{a}$ & $\mathrm{n} / \mathrm{a}$ & $\mathrm{n} / \mathrm{a}$ & $\mathrm{n} / \mathrm{a}$ & $\mathrm{n} / \mathrm{a}$ & $\mathrm{Vl}$ & $\mathrm{n} / \mathrm{a}$ \\
\hline 14 & 0.05 & +++ & 1200 & $\mathrm{n} / \mathrm{a}$ & $n / a$ & $\mathrm{n} / \mathrm{a}$ & $\mathrm{n} / \mathrm{a}$ & $\mathrm{n} / \mathrm{a}$ & $\mathrm{Vl}$ & $\mathrm{n} / \mathrm{a}$ \\
\hline 15 & 2.71 & ++ & $\mathrm{n} / \mathrm{a}$ & $\mathrm{n} / \mathrm{a}$ & $\mathrm{n} / \mathrm{a}$ & $\mathrm{n} / \mathrm{a}$ & $\mathrm{n} / \mathrm{a}$ & $\mathrm{n} / \mathrm{a}$ & $\mathrm{Vl}$ & $\mathrm{n} / \mathrm{a}$ \\
\hline 16 & 2.99 & + & $\mathrm{n} / \mathrm{a}$ & $\mathrm{n} / \mathrm{a}$ & $\mathrm{n} / \mathrm{a}$ & $\mathrm{n} / \mathrm{a}$ & $\mathrm{n} / \mathrm{a}$ & $\mathrm{n} / \mathrm{a}$ & $\mathrm{Vl}$ & $\mathrm{n} / \mathrm{a}$ \\
\hline 19 & $\mathrm{n} / \mathrm{a}$ & $\mathrm{n} / \mathrm{a}$ & 1208 & $\mathrm{n} / \mathrm{a}$ & $\mathrm{n} / \mathrm{a}$ & $\mathrm{n} / \mathrm{a}$ & $\mathrm{n} / \mathrm{a}$ & $\mathrm{n} / \mathrm{a}$ & III & $\mathrm{n} / \mathrm{a}$ \\
\hline 20 & $\mathrm{n} / \mathrm{a}$ & $\mathrm{n} / \mathrm{a}$ & 1162 & $\mathrm{n} / \mathrm{a}$ & $\mathrm{n} / \mathrm{a}$ & $\mathrm{n} / \mathrm{a}$ & $\mathrm{n} / \mathrm{a}$ & n/a & IV & $\mathrm{n} / \mathrm{a}$ \\
\hline \multicolumn{11}{|c|}{ Immunized non-ADD* } \\
\hline $21 \mathrm{PSP}$ & 0.75 & 0 & $\mathrm{n} / \mathrm{a}$ & $\mathrm{n} / \mathrm{a}$ & $n / a$ & $\mathrm{n} / \mathrm{a}$ & $\mathrm{n} / \mathrm{a}$ & $\mathrm{n} / \mathrm{a}$ & $\mathrm{n} / \mathrm{a}$ & $\mathrm{n} / \mathrm{a}$ \\
\hline $22 \mathrm{HS}$ & $\mathrm{n} / \mathrm{a}$ & $\mathrm{n} / \mathrm{a}$ & 1280 & $\mathrm{n} / \mathrm{a}$ & $\mathrm{n} / \mathrm{a}$ & $\mathrm{n} / \mathrm{a}$ & $\mathrm{n} / \mathrm{a}$ & n/a & $\mathrm{n} / \mathrm{a}$ & $\mathrm{n} / \mathrm{a}$ \\
\hline
\end{tabular}

NDC, non-demented controls; AD, Alzheimer's disease; non-ADD, non-Alzheimer's disease dementias; PSP, progressive supranuclear palsy; HS, hippocampal sclerosis; WMR, white matter rarefaction; NFT, neurofibrillary tangle; NP, neuritic plaque; CAA, cerebral amyloid angiopathy; n/a, not available. Plaque clearance designations correspond to 0 , none; + , little evidence or active process; ++ , moderate/patchy; +++ , complete.

${ }^{*}$ A 342 load and Braak stage for USSM cases taken from Holmes, et al [29], Boche, et al [30] and Boche, et al [35].

Mannheim, Germany). The homogenates were centrifuged at $435,000 \times g$ for $20 \mathrm{~min}$ in an Optima TLAultracentrifuge using a 120.2 rotor (Beckman, Fullerton, $\mathrm{CA})$. The supernatant was saved as the soluble $A \beta$ fraction and total protein quantified with the Pierce BCA protein assay (Rockford, IL). Four-hundred mg each of gray and white matter tissue was homogenized in $3 \mathrm{ml}$ of $90 \%$ glass distilled formic acid (GDFA) and centrifuged at $250,000 \times g$ for 20 min at $4^{\circ} \mathrm{C}$ in an Beckman LE-80K ultracentrifuge using a SW41 rotor (Beckman). The supernatant was collected carefully avoiding the top fat layer. Specimens were homogenized in 90\% GDFA with the aim of fully solubilizing all forms of $A \beta$ (fibrillar, diffuse, membrane-bound, and intra- and extra- cellular oligomeric species). High-speed centrifugation permitted the removal of all lipids including membraneassociated forms which are totally disrupted by the GDFA and form a compact aggregate at the top of the centrifuge tube. The entire volume from each case was submitted to fast protein liquid chromatography (FPLC) size-exclusion Superose-12 chromatography in $80 \%$ GDFA mobile phase (see below). The A $\beta$ peptidecontaining fractions were collected and pooled from each run and reduced to $2 \mathrm{ml}$ by vacuum centrifugation (SpeedVac; Savant/Thermo, Waltham, MA). To remove the acid, each case was dialyzed in $1000 \mathrm{MW}$ cutoff tubing against 2 changes of water $(1 \mathrm{~h}$ each) and 2 changes of $0.1 \mathrm{M}$ ammonium bicarbonate solution ( $1 \mathrm{~h}$ each). 
Table 3 Summary of Clinico-Neuropathology Analysis in UCSD AN-1792-Immunized Cases

\begin{tabular}{llllllll}
\hline Case ID & Blessed [63] & MMSE & Total plaque & Neuritic plaques & Tangles & CAA & Neuropathology diagnosis \\
\hline 19 & 26 & 8 & 23 & 7 & 0 & 3 & Lewy body Variant of AD \\
20 & 17 & 18 & 50 & 0 & 0 & 2 & AD \\
22 & 28 & 10 & 4 & 3 & 0 & 0 & HS, severe frontal lobe atrophy \\
\hline
\end{tabular}

MMSE, mini-mental state examination; CAA, cerebral amyloid angiopathy; AD, Alzheimer's diease; HS, hippocampal sclerosis. The counts are representative from the frontal cortex. For each case, 3 sections were analyzed. Total plaques include diffuse and mature with a maximum score of 50 ( $100 \times$ magnification). Neuritic plaques are defined as those containing a corona of dystrophic neurites with a maximum score of $50(100 \times$ magnification). Tangles were assessed at $400 \times$ magnification with a maximum score of 50 . CAA was assessed as 0 , none; 1 , mild; 2 , moderate; 3 , severe using thioflavine-S staining.

Samples were freeze-dried and lyophilized. The samples were then reconstituted in $500 \mu \mathrm{l}$ of $5 \mathrm{M}$ guanidine hydrochloride $(\mathrm{GHCl})$ prepared in $50 \mathrm{mM}$ Tris- $\mathrm{HCl}, \mathrm{pH}$ 8.0 and shaken overnight at $4{ }^{\circ} \mathrm{C}$. Total protein was quantified by the Pierce BCA protein assay. The ELISA kits to quantify $A \beta 40$ and $A \beta 42$ were obtained from Invitrogen (Carlsbad, CA) and Innogenetics (Gent, Belgium), respectively, and performed following the manufacturer's instructions.

\section{Quantification of tumor necrosis factor- $\alpha$ (TNF- $\alpha$ ) by ELISA}

All steps were performed at $4{ }^{\circ} \mathrm{C}$ and followed a previously published protocol [37]. Gray matter (100 mg) was homogenized in 20 volumes of $20 \mathrm{mM}$ HEPES, 1.5 mM EDTA, pH 7.4 in PIC (Roche) with an Omni TH electric tissue grinder and the samples centrifuged at $3000 \times g$ for $15 \mathrm{~min}$ in an IEC Centra CL3R centrifuge (Thermo, Waltham, MA). The supernatant was then collected and centrifuged at 40,000 $\times g$ for $1 \mathrm{~h}$ with a $50.4 \mathrm{Ti}$ rotor (Beckman) and Optima LE-80K ultracentrifuge (Beckman). The supernatant was again collected and total protein determined with a BCA protein assay (Pierce). Human TNF- $\alpha$ levels were measured with a kit from PromoKine (Heidelberg, Germany) according to the manufacturer's instructions.

\section{Western Blot Analysis}

Western blots were performed as previously described [38]. Briefly, gray matter was homogenized in RIPA buffer (Sigma, St. Louis, MO), containing PIC (Roche). The homogenates were centrifuged, the supernatants collected and total protein quantified with a BCA protein assay kit (Pierce). The samples ( $25 \mu \mathrm{g}$ of total protein loaded per lane) were separated by SDS-PAGE and then electrophoretically transferred onto $0.45 \mu \mathrm{m}$ pore nitrocellulose membranes (Invitrogen), blocked with $5 \%$ non-fat milk in phosphate-buffered saline (PBS), 0.5\% Tween 20 (Fluka, St. Louis, MO). The primary antibodies used in the experiments included 22C11 (recognizes amino acids 66-81 of APP; Millipore, Billerica, MA), CT9APP (recognizes the last 9 C-terminal amino acids of APP; Millipore) and antitau HT7 (recognizes amino acids 159-163; Pierce). The secondary antibodies used were either goat anti-mouse IgG conjugated horseradish peroxidase (HRP; 22C11 and anti-tau) or goat anti-rabbit IgG conjugated HRP (CT9APP) from Pierce. Protein signals were detected with SuperSignal WestPico Chemiluminescent (Pierce) substrate, CL-Xpose film (Pierce) and Kodak GBX developer and fixer (Sigma). Analysis was performed with a GS-800 calibrated densitometer (Bio-Rad, Hercules, CA) and Quantity One software (Bio-Rad). All membranes were stripped with Restore ${ }^{\mathrm{TM}}$ Western Blot Stripping Buffer (Pierce), washed in PBS and then re-blocked. Anti-mouse or anti-rabbit actin antibodies (Abcam, Cambridge, MA) were used to re-probe the blots for total protein normalization.

\section{Fast protein liquid chromatography}

Cerebral cortex $(\sim 3 \mathrm{~g})$ was minced and homogenized in $18 \mathrm{ml}$ of $90 \%$ GDFA, allowed to stand at room temperature for $15 \mathrm{~min}$ and centrifuged at $240,000 \times g$ for $1 \mathrm{~h}$ at $4{ }^{\circ} \mathrm{C}$. The separated lipid layer collected at the top of the tube was carefully removed and the small pellet at the bottom of the tube discarded. The intermediate supernatant was divided into $500 \mu \mathrm{l}$ portions and frozen at $-80^{\circ} \mathrm{C}$. Each aliquot was submitted to size-exclusion FPLC using a Superose 12 column $(10 \times 300 \mathrm{~mm}$, General Electric, Uppsala, Sweden), equilibrated with $80 \%$ GDFA. The chromatography was developed using $80 \%$ GDFA at a flow rate of $15 \mathrm{ml}$ per h at room temperature and monitored at $280 \mathrm{~nm}$. The fraction that eluted between 50-66 minutes, containing 2-8 kDa $\mathrm{M}_{\mathrm{r}}$ molecules, was collected and reduced to $\sim 50 \mu \mathrm{l}$ by vacuum centrifugation (Savant Instruments Inc), and stored at $-80^{\circ} \mathrm{C}$.

\section{High performance liquid chromatography (HPLC)}

The 2-8 kDa FPLC fractions were separated by reversephase HPLC using a C8 column $(4.6 \times 250 \mathrm{~mm}$, Zorbax SB, Mac Mod) using a linear gradient from 0-60\% wateracetonitrile concentration containing $0.1 \%$ trifluoroacetic acid (TFA), developed at a flow rate of $1 \mathrm{ml}$ per min over $120 \mathrm{~min}$ at $80^{\circ} \mathrm{C}$. Absorbance was monitored at $214 \mathrm{~nm}$ and a total of 9 fractions collected and reduced in volume by vacuum centrifugation. To eliminate the acid, the specimens were washed with three changes of water $(200 \mu \mathrm{l}$ 
each) and the volume reduced by vacuum centrifugation. After the last wash, the volume was reduced and the samples re-solubilized in 2xLDS sample loading buffer (Invitrogen) with $50 \mathrm{mM}$ dithiothreitol. Western blots were conducted as described above with anti-A $\beta 40$ and anti-A $\beta 42$ (Invitrogen) and CT9APP (Millipore) as primary antibodies and goat $\alpha$-rabbit IgG HRP as the secondary antibody.

\section{Surface enhanced laser desorption/ionization-time of flight mass spectrometry (SELDI-TOF) mass spectrometry (MS). A $\beta 40 / 42$ Method}

HPLC peaks that were analyzed using Western blots and found to contain A $\beta$ were subjected to SELDI-TOF MS following a previously published protocol [39]. Briefly, the capture antibodies, anti-A $\beta 40$ and anti-A $\beta 42$ antibodies (Invitrogen), were loaded onto PS20 ProteinChip arrays (Bio-Rad, Hercules, CA) at a concentration of $0.38 \mathrm{mg} / \mathrm{ml}$. Either the HPLC A $\beta$-containing peaks or A $\beta 1-40$ or 1-42 peptide standards (positive controls) were then applied. The molecular mass assignments resulted from 100 averaged shots in a Bio-Rad SELDI Protein Biology System II with external calibration attained using the ProteinChip Peptide Mass Calibration Kit (Bio-Rad).

\section{SELDI-TOF MS, 6E10 Method, ProteinChip $\beta$-Amyloid MPD Kit}

The HPLC peaks containing $A \beta$ were pooled together to yield one combined sample per case. All steps were performed at room temperature. The internal standard and calibrants were prepared according to the manufacturer's instructions (Bio-Rad). To each HPLC and calibrant sample (A $\beta$ peptides: 1-16, 1-38, 1-40 and 1-42), $50 \mu \mathrm{l} / \mathrm{ml}$ of the internal standard A $\beta$ Cys $1-24\left(\mathrm{M}_{\mathrm{r}}=\right.$ 2,979.3) was added. Each spot on the ProteinChip arrays was equilibrated with $5 \mu$ l of PBS for $5 \mathrm{~min}$, then loaded with $5 \mu \mathrm{l}$ of sample or calibrant and incubated in a humidified chamber for $1 \mathrm{~h}$. The samples/calibrants were removed and each array was washed 3 times in a $15 \mathrm{ml}$ conical tube with $10 \mathrm{ml}$ of wash buffer (PBS, $0.5 \%$ Triton X-100) for 5 min each then 3 times in PBS for 5 min each. To desalt the arrays, each chip was washed in $10 \mathrm{ml}$ of $0.1 \mathrm{M}$ HEPES for $5 \mathrm{~min}$ and then air dried. To $5 \mathrm{mg}$ of $\alpha$-cyano-4-hydroxycinnamic acid (CHCA), 200 $\mu \mathrm{l}$ of acetonitrile and $200 \mu \mathrm{l}$ of $1.0 \%$ TFA were added. The solution was vortexed for $2 \mathrm{~min}$ then centrifuged at $1000 \times g$ for $1 \mathrm{~min}$ to remove particulates. A $20 \%$ solution of $\mathrm{CHCA}$ was made from the saturated CHCA (diluted in a 1:1 ratio of acetonitrile and 1.0\% TFA) and vortexed for $1 \mathrm{~min}$. The $20 \% \mathrm{CHCA}$ solution was applied $(1 \mu \mathrm{l})$ to each spot and air dried. The molecular mass assignments and calibration was performed as described above.

\section{Results}

\section{Clinical and Neuropathological Observations}

We examined 9 individuals clinically diagnosed with AD who were treated with the AN-1792 immunotherapy. Whole mount preparations of cortical blood vessels of cases \# 19, 20 and 22, after removal of brain parenchyma by SDS, revealed the presence of insoluble CAA (Figure 1). For comparative reference, Table 2 shows the neuropathological parameters observed in 5 NDC individuals (cases \# 1-5) and 6 non-immunized AD patients (cases \# 6-11). The neuropathological changes observed in 5 immunized cases originating from USSM (cases \# 12 -16), who were treated with the AN-1792 antigen, were described in previous publications $[29,30,35]$. Their A $\beta 42$ load and semi-quantitatively estimated degree of plaque clearance and Braak stage are given in Table 2. This group of individuals each received 7-8 antigen injections, at 50 or $225 \mu \mathrm{g}$ per dose, and had an average survival time of 62 months (range 44-86 months) after the initial immunization (Table 1). Four of these individuals were ApoE genotyped, and of these, three were carriers of the ApoE $\varepsilon 4$ allele.

The USSM case \# 21, clinically diagnosed as having $\mathrm{AD}$, received 6 immunizations of $50 \mu \mathrm{g}$ each (Table 1 ). However, on neuropathological examination, this case was reclassified as PSP. Accordingly, the A $\beta 42$ load was very low $(0.75 \%)$ (Table 2$)$, and the levels of soluble and insoluble $A \beta$ as measured by ELISA were also negligible (Table 4).

Table 3 gives an account of clinical and neuropathological data for the three cases provided by UCSD. Cases \# 19 and \# 20 were recognized after postmortem neuropathological examination as Lewy body variant of AD and $\mathrm{AD}$, respectively. The immunized patient \# 22, clinically diagnosed as $\mathrm{AD}$, was found to be a case of HS on neuropathological examination and also had low levels of $A \beta$ compared to the average of the immunized AD group (Table 4). All three individuals received only a single dose of the AN-1792 antigen.

\section{A $\beta$ ELISA Quantification}

Pivotal in the assessment of immunotherapy effectiveness is the quantification of $A \beta 40, A \beta 42$ and total $A \beta$ peptides by ELISA, as Tris-soluble and GDFA/GHCl-soluble forms in gray matter (GM) and white matter (WM). Frozen WM was not available from USSM for ELISA analysis. These values are shown in Table 4. For comparison, analogous values observed in non-immunized AD and NDC individuals are also presented in Table 4. Significant differences in A $\beta$ levels between the NDC and AD populations in both GM and WM tissue compartments were observed for GM GDFA/GHCl A $\beta 42$ and total A $\beta$ GM GDFA/GHCl levels ( $p=0.0026$ and 0.0066, respectively, unpaired, 2 -tailed $\mathrm{t}$-test). 

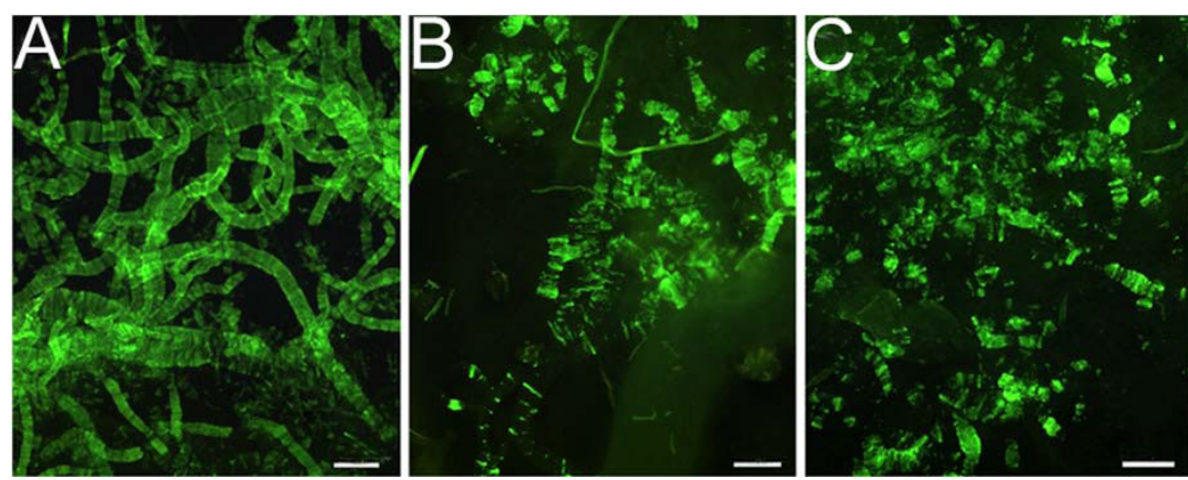

Figure 1 Thioflavin-S of blood vessels to assess CAA in UCSD cases using SDS lysates of cerebral cortex. A) Case \# 19 demonstrated severe CAA. B) Case \# 20 showed moderate CAA. C) Case \# 22 exhibits moderate CAA, although this case was neuropathologically reported as having no CAA (Table 3). These differences may be due to different methodological assessments or sampling sites. Scale bar $=250 \mu \mathrm{m}$.

The overall degree of variability in the total $\mathrm{A} \beta$ levels in the GM of the immunized AD cases is enormous, ranging from 283 to $14,011 \mathrm{ng} / \mathrm{mg}$ total protein (mean $=6,544$ ) for GDFA/GHCl-soluble species and from 0 to $13,431 \mathrm{pg} / \mathrm{mg}$ of total protein (mean $=3,467$ ) for the corresponding Tris-soluble $A \beta$ fractions (Table 4). There are remarkable differences concerning the final outcome of immunotherapy as illustrated by subjects \# 13 and 14. Both individuals received $8 \mathrm{AN}-1792$ injections of $50 \mu \mathrm{g}$ (Table 1). In the latter case, the histological observations $[29,30]$ were matched by ELISA quantification which revealed comparatively lesser amounts of total soluble and insoluble $A \beta$ peptides, while case \# 13 had the second highest levels of GDFA/GHCl-soluble A $\beta$ and the highest levels of Trissoluble $A \beta$ observed. In contrast, case \# 14 had the lowest levels of $A \beta$ in both solvents compared to the immunized group. In these two individuals, the survival time since the first immunization was almost identical: 57 and 60 months, illustrating that the presence or absence of $A \beta$ amyloid plaque pathology was apparently irrelevant for the progression and fatal outcome with $\mathrm{AD}$ dementia.

A comparison of the average $A \beta$ levels between immunized and non-immunized AD groups also demonstrates large overall differences in soluble and insoluble $A \beta$ content (Table 4). There is a statistically significant difference in the GDFA/GHCl-soluble $\mathrm{A} \beta 42$ between immunized and non-immunized individuals $(\mathrm{p}=0.039)$, being lower in the former group. On the other hand, the levels of $A \beta 40$ were increased paradoxically in the immunized cohort, almost to twice the mean quantities observed in the non-immunized AD control group, although the difference did not reach statistical significance. In one immunized individual (case \# 14) the level of total Tris-soluble $A \beta$ fell below the limit of detection. The mean of the remaining 6 immunized individuals was 22 times greater than the mean observed in the nonimmunized AD cases.
Given the high degree of pathological variability encountered among NDC, $A D$ and $A \beta$-immunized $A D$ patients, as shown in Table 4, it is also important to consider weighing the data individually, rather than exclusively working with group mean values. For example, in the NDC group, both GM and WM GDFA/ GHCl-soluble $\mathrm{A} \beta$ levels of case \# 5 were abnormally high for this group and consequently skews the average values for this group upward to a range of 4-5-fold greater than the mean of the other members of the NDC group. Hence, this case should be classified as a non-demented 'high pathology control'. In the AD group, the GDFA/GHCl-soluble $\mathrm{A} \beta$ in WM of individual \# 11 is abnormally high for this group and again skews the average values upward, being 7 times greater than the mean value observed in the rest of the group. In the immunized group, the WM GDFA/GHCl-soluble total $\mathrm{A} \beta$ level in case \# 20 is 13 times greater than the values observed for case \# 19. In the Tris-soluble $A \beta$ fraction, the immunized AD individuals \# 13 and \# 16 have 21 - and 12 -fold more $A \beta$, respectively, than the remaining 5 individuals in this group. These elevated values are also reflected, although to a lesser degree, in the GM GDFA/GHCl-soluble A $\beta$ fractions and are correlated with only moderate and mild plaque clearance $[29,30]$. Dixon's Q test [40] also identified these individuals as outliers.

Interestingly, 3 of the 7 immunized neuropathologically confirmed AD cases had a total GM GDFA/GHClsoluble $A \beta$ values substantially lower than the mean of the 6 non-immunized AD cases $(7218 \mathrm{ng} / \mathrm{mg}$ total protein), suggesting that the antibodies may have removed $\mathrm{A} \beta$ in these cases. The remaining 4 immunized cases had values equal to or higher than the mean observed in the non-immunized AD group.

As mentioned above, of the 3 cases treated with the AN-1792 immunogen that were provided by UCSD, one 
Table 4 ELISA quantification of TNF- $\alpha, A \beta 40$ and $A \beta 42$

\begin{tabular}{|c|c|c|c|c|c|c|c|c|c|c|}
\hline & \multirow{2}{*}{$\begin{array}{l}\text { GM } \\
\text { TNF- } \alpha \text { pg/ } \\
\text { mg total } \\
\text { protein* }\end{array}$} & \multicolumn{3}{|c|}{ GM GDFA/GHCl-soluble $A \beta$} & \multicolumn{3}{|c|}{ WM GDFA/GHCl-soluble $A \beta$} & \multicolumn{3}{|c|}{ GM Tris-soluble $A \beta \beta$} \\
\hline & & $\begin{array}{l}\mathrm{A} \beta 40 \mathrm{ng} / \\
\mathrm{mg} \text { total } \\
\text { protein }\end{array}$ & $\begin{array}{l}\text { A } \beta 42 \mathrm{ng} / \\
\text { mg total } \\
\text { protein**\# }\end{array}$ & $\begin{array}{l}\text { Total A } \beta \mathrm{ng} / \\
\text { mg total } \\
\text { protein }\end{array}$ & $\begin{array}{l}\mathrm{A} \beta 40 \mathrm{pg} / \\
\mathrm{mg} \text { total } \\
\text { protein }\end{array}$ & $\begin{array}{l}\mathrm{A} \beta 42 \mathrm{pg} / \\
\mathrm{mg} \text { total } \\
\text { protein }\end{array}$ & $\begin{array}{l}\text { Total } A \beta \\
\text { pg/mg total } \\
\text { protein }\end{array}$ & $\begin{array}{l}\mathrm{A} \beta 40 \mathrm{pg} / \\
\mathrm{mg} \text { total } \\
\text { protein }\end{array}$ & $\begin{array}{l}\mathrm{A} \beta 42 \mathrm{pg} / \\
\text { mg total } \\
\text { protein }\end{array}$ & $\begin{array}{l}\text { Total } A \beta \\
\mathrm{pg} / \mathrm{mg} \text { total } \\
\text { protein }\end{array}$ \\
\hline \multicolumn{11}{|l|}{ NDC } \\
\hline 1 & 24 & 15 & 488 & 503 & 102 & 454 & 556 & 0 & 0 & 0 \\
\hline 2 & 13 & 82 & 911 & 993 & 82 & 428 & 510 & 166 & 438 & 604 \\
\hline 3 & 14 & 4 & 105 & 109 & 83 & 429 & 512 & 0 & 0 & 0 \\
\hline 4 & 12 & 56 & 920 & 976 & 66 & 570 & 636 & 0 & 0 & 0 \\
\hline 5 & 17 & 167 & 2168 & 2335 & 81 & 2596 & 2677 & 0 & 142 & 142 \\
\hline Mean & 16 & 65 & 918 & 983 & 87 & 836 & 923 & 28 & 97 & 124 \\
\hline
\end{tabular}

\begin{tabular}{lllllllllll} 
AD & & & & & & & & \\
6 & 11 & 5405 & 8152 & 13557 & 101 & 4122 & 4223 & 116 & 138 & 254 \\
7 & 13 & 374 & 5910 & 6284 & 923 & 2379 & 3302 & 0 & 88 & 88 \\
8 & 13 & 179 & 4773 & 4952 & 90 & 5156 & 5246 & 148 & 93 & 241 \\
9 & 13 & 394 & 2664 & 3058 & 136 & 965 & 1101 & 254 & 66 & 320 \\
10 & 15 & 96 & 5344 & 5440 & 91 & 1931 & 2022 & 0 & 35 & 35 \\
11 & 18 & 7169 & 2847 & 10016 & 8940 & 13669 & 22609 & 151 & 0 & 151 \\
Mean & $\mathbf{1 4}$ & $\mathbf{2 2 6 9}$ & $\mathbf{4 9 4 8}$ & $\mathbf{7 2 1 8}$ & $\mathbf{1 7 1 4}$ & $\mathbf{4 7 0 4}$ & $\mathbf{6 4 1 7}$ & $\mathbf{1 1 2}$ & $\mathbf{7 0}$ & $\mathbf{1 8 2}$ \\
\hline
\end{tabular}

\section{Immunized AD}

\begin{tabular}{|c|c|c|c|c|c|c|c|c|c|c|}
\hline 12 & 45 & 6347 & 58 & 6405 & - & - & - & 1260 & 0 & 1260 \\
\hline 13 & 37 & 9925 & 1226 & 11151 & - & - & - & 13169 & 262 & 13431 \\
\hline 14 & 32 & 252 & 31 & 283 & - & - & - & 0 & 0 & 0 \\
\hline 15 & 32 & 1067 & 421 & 1488 & - & - & - & 629 & 26 & 655 \\
\hline 16 & 43 & 8568 & 1570 & 10138 & - & - & - & 7556 & 142 & 7698 \\
\hline 19 & 33 & 764 & 1565 & 2329 & 661 & 2141 & 2802 & 498 & 0 & 498 \\
\hline 20 & 34 & 6315 & 7696 & 14011 & 7363 & 29669 & 37032 & 565 & 160 & 725 \\
\hline Mean & 34 & 4748 & 1795 & 6544 & 4012 & 15905 & 19917 & 3382 & 84 & 3467 \\
\hline
\end{tabular}

Immunized non-ADD

\begin{tabular}{llllllllll}
21 & 30 & 1 & 18 & 19 & - & 0 & 0 \\
PSP & & 18 & & & 0 & 0 \\
$22 \mathrm{HS}$ & 13 & 3 & 333 & 336 & 158 & 1245 & 1403 & 0 \\
\hline
\end{tabular}

${ }^{*} \mathrm{p}<0.0001 ;{ }^{* *} \mathrm{p}=0.026 ;{ }^{* * *} \mathrm{p}=0.007$ unpaired, 2-tailed t-tests between AD and NDC cases. \# $\mathrm{p}=0.039$ unpaired, 2 -tailed t-tests between non-immunized and immunized AD individuals. NDC, non-demented control; AD, Alzheimer's disease; non-ADD, non-Alzheimer's disease dementias; TNF, tumor necrosis factor; GM, gray matter; WM, white matter; GHCl, guanidine hydrochloride, GDFA, glass-distilled formic acid; PSP, progressive supranuclear palsy; HS, hippocampal sclerosis.

was neuropathologically diagnosed as HS. The remaining 2 individuals, cases \# 19 and \#20, exhibited the neuropathology of $\mathrm{AD}$, as shown in Table 3 . From the A $\beta$ immunoassay standpoint, case \# 19 had relatively moderate levels of GM and WM GDFA/GHCl-soluble $\mathrm{A} \beta$ peptides as well as Tris-soluble $A \beta$. In contrast, case \# 20 showed the highest levels of GM and WM GDFA/ $\mathrm{GHCl}$-soluble $\mathrm{A} \beta$ peptides of the 20 cases under investigation including the $5 \mathrm{NDC}$ and 6 non-immunized AD cases that served as controls.

In addition, there was also a high degree of variability in antibody response (Table 1). For example, case \# 12 and case \# 14 had the highest antibody titers, but from a neuropathological point of view, case \# 12 had little evidence of plaque removal, while case \# 14 had extensive $A \beta$ clearance. The A $\beta$ ELISA data also show a similar pattern for case \# 12 and case \#14 (Table 4). Case \# 15 had a relatively low antibody titer, but demonstrated a moderate amount of $A \beta$ clearance (Table 2). Case \# 21 had a low antibody titer which in the immunization context was irrelevant, since this was in an individual with PSP.

\section{Apolipoprotein E genotype}

Six out of seven patients neuropathologically diagnosed as $\mathrm{AD}$ were ApoE genotyped. Five of them were carriers for the $\varepsilon 4$ allele (Table 1). There was no direct 
correlation between the ApoE status and the total amount of GM A $\beta$ extracted by GDFA/GHCl or those present in the Tris-soluble fractions (Table 4).

\section{Tumor necrosis factor- $\alpha$ ELISA quantification}

Tumor necrosis factor- $\alpha$ is a proinflammatory cytokine which was elevated by an average of 2.4 times in ADimmunized individuals when compared to the mean levels observed in non-immunized AD (34 pg/mg total protein, $14 \mathrm{pg} / \mathrm{mg}$ total protein, respectively; $\mathrm{p}<0.0001$, Table 4). It is noteworthy that even in the immunized $\mathrm{AD}$ patient with the most marked reduction in $\mathrm{A} \beta$ (\# $14)$, the TNF- $\alpha$ level remained higher than in the nonimmunized AD group (Table 4).

\section{Western blots of gray matter homogenates}

Cerebral cortex from the 9 immunized cases was directly homogenized in RIPA buffer and analyzed by Western blots using the 22C11, CT9APP and tau HT7 antibodies. For comparison, 4-5 AD and 4 NDC cases were also incorporated. The N-terminal-directed antibody $22 \mathrm{C} 11$ demonstrated no significant differences in total APP among the immunized cases as compared to non-immunized AD and NDC individuals (Figure 2A). However, there were some fluctuations in the amount of $25 \mathrm{kDa}$ APP N-terminal peptide (Figure 2A). The CT9APP antibody detected the CT99/83 at $\sim 13 \mathrm{kDa}$ and a band at $\sim 40 \mathrm{kDa}$ which was present in all specimens under investigation (Figure 2B). This peptide, revealed by the CT9APP antibody, is of interest because a band of similar size is also present in PS mutations in sporadic AD and in NDC cases [38] as well as in the triple transgenic mice (3XTg) engineered by LaFerla et al. (A. Roher, unpublished observations). Further investigation is needed to clarify the nature of this putatively longer APP C-terminal peptide and its proteolytic products. There was no difference in the levels of CT99 ( 13 kDa band) between the AD immunized cases and non-immunized AD cases. It is possible that the 25 and the $40 \mathrm{kDa}$ bands represent complementary $\mathrm{N}$-terminal and $\mathrm{C}$-terminal species derived from the unmodified APP molecule. The CT9APP antibody also revealed that the amount of total APP was moderately decreased in the immunized cases when compared to non-immunized AD and NDC groups, although 22C11 did not show this trend. This antibody also demonstrated two additional APP C-terminal related bands at $\sim 58$ and $\sim 75 \mathrm{kDa}$ (Figure 2B). These observations go with the caveat that 22C11 and CT9APP can cross react with amyloid precursor-like protein (APLP). An overall comparison of the Western blot HT7 tau antibody pattern demonstrated no significant differences among AD immunized and non-immunized samples, with the exception of the AD cases \# 7 and \# 9 that exhibited a SDS-resistant dimeric form of tau (Figure 2C).

\section{Column Chromatography}

After initial separation by FPLC, the fractions containing the $A \beta$ peptides which were eluted between 50-62 min (equivalent to $12.5-15.5 \mathrm{ml}$ of elution solvent), were separated through C8 reverse-phase HPLC (Figure 3). Biochemical characterization by Western blot was performed on 3 of the immunized cases. Case \# 19 had a decreased amount of predominantly dimeric $A \beta 42$ peptides relative to $A \beta 40$ isoforms (Figure 3A). The AN-1792 case \# 20, on the other hand, had equimolar levels of $A \beta 40$ and $A \beta 42$ peptides (Figure 3B). The HS case \# 22 had very small amounts of $A \beta 40$ and a more abundant complement of $A \beta 42-$ related peptides. Western blots probed with CT9APP antibody demonstrated the presence of the expected CT99 and CT83 APP C-terminal fragments at about $13 \mathrm{kDa}$ in Figure 3C. In addition, they also showed a peptide band with a $\mathrm{M}_{\mathrm{r}}$ of $\sim 40 \mathrm{kDa}$.

\section{Mass spectrometry}

In a previous study dealing with the remnant $A \beta$-related peptides left in the brains of $2 \mathrm{AD}$ individuals immunized with the AN-1792, we identified a large number of peptides by matrix-assisted laser desorption/ionization-time of flight mass spectrometry (MALDI-TOF MS). The presence of these peptides was confirmed by reflectron MALDI-TOF in their monoisotopic $M_{r}$ form [28]. In the present investigation, 3 (cases \# 20-22, from UCSD) out of the 9 cases under study were investigated by mass spectrometry. SELDI-TOF MS was used to identify the $A \beta$-related peptides using $A \beta 40, A \beta 42$ and $6 E 10$ as capture antibodies. An assortment of $A \beta$-related peptides were identified with $\mathrm{N}$-termini starting at 1, 2, 3-pyroglutamyl (3pE), 4, 5, 6, 11, and 17 and C-termini ending at 40, 42, 43, 46, 47, 49, 50, 61, 62, 68, 73, 82, 96 and 99 (data given in the $A \beta$-related amino acid sequencing, where residue 99 corresponds to residue 695 of the $\mathrm{APP}_{695}$ molecule, see Table 5). Dimers of $A \beta 2-40$ and $1-43$ as well as dimeric $A \beta$ hybrids identified as $3 p E-40+$ 4-40 and 3pE-40+2-40 were observed. As can be appreciated, there are several longer $A \beta$-related peptides covering amino acid sequences beyond the transmembrane domain of the APP. Our studies revealed secretase cleavage at the $\beta$-sites 1 and 11 , at the $\alpha$-site 17 , and at putative $\gamma$-sites $40,42,43,46,47,49$, and 50 . Shorter $N$ terminal $\mathrm{A} \beta$ sequences were found starting at residues 2 , $3,4,5$, and 6 , probably resulting from aminopeptidase activity, as it is commonly observed in all AD cases [41]. Post-translational modifications such as cyclization of residue 3 glutamyl to pyroglutamyl [42] oxidation of Met and random formylation of Ser and Thr were also observed. The latter modification was probably an artifact of exposure of the specimens to formic acid. Although quantification of peptides by MS is difficult to achieve 


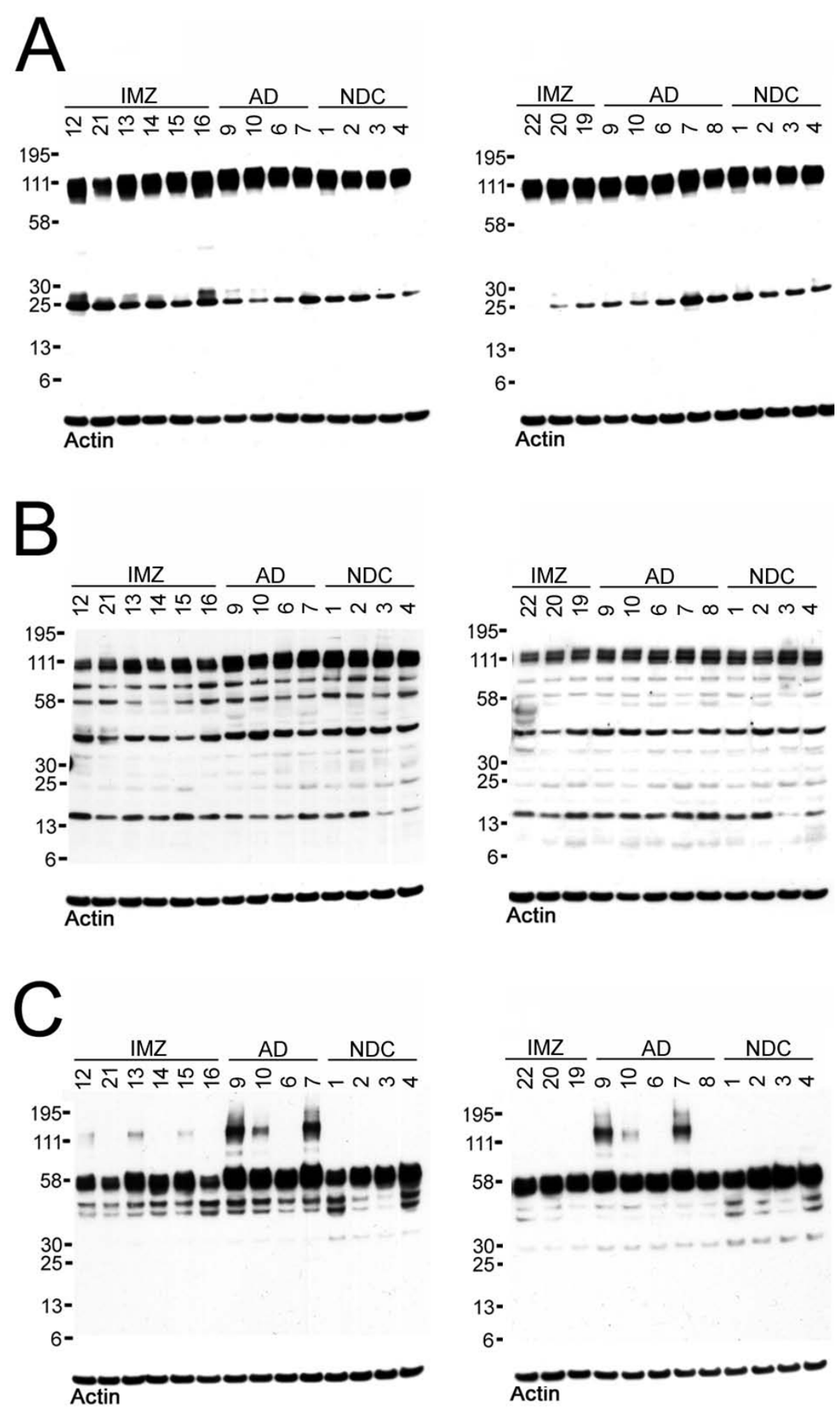

Figure 2 Western blots of GM homogenates. A total of $25 \mu \mathrm{g}$ of protein was loaded in each lane. A) $22 \mathrm{C} 11$ against amino acid residues $66-$ 81 of APP, B) CT9APP against the last nine amino acid residues of APP and C) tau HT7 against amino acid residues 159-163 of tau. For further details see the Results Section. IMZ, immunized; AD, Alzheimer's disease; NDC, non-demented control. 


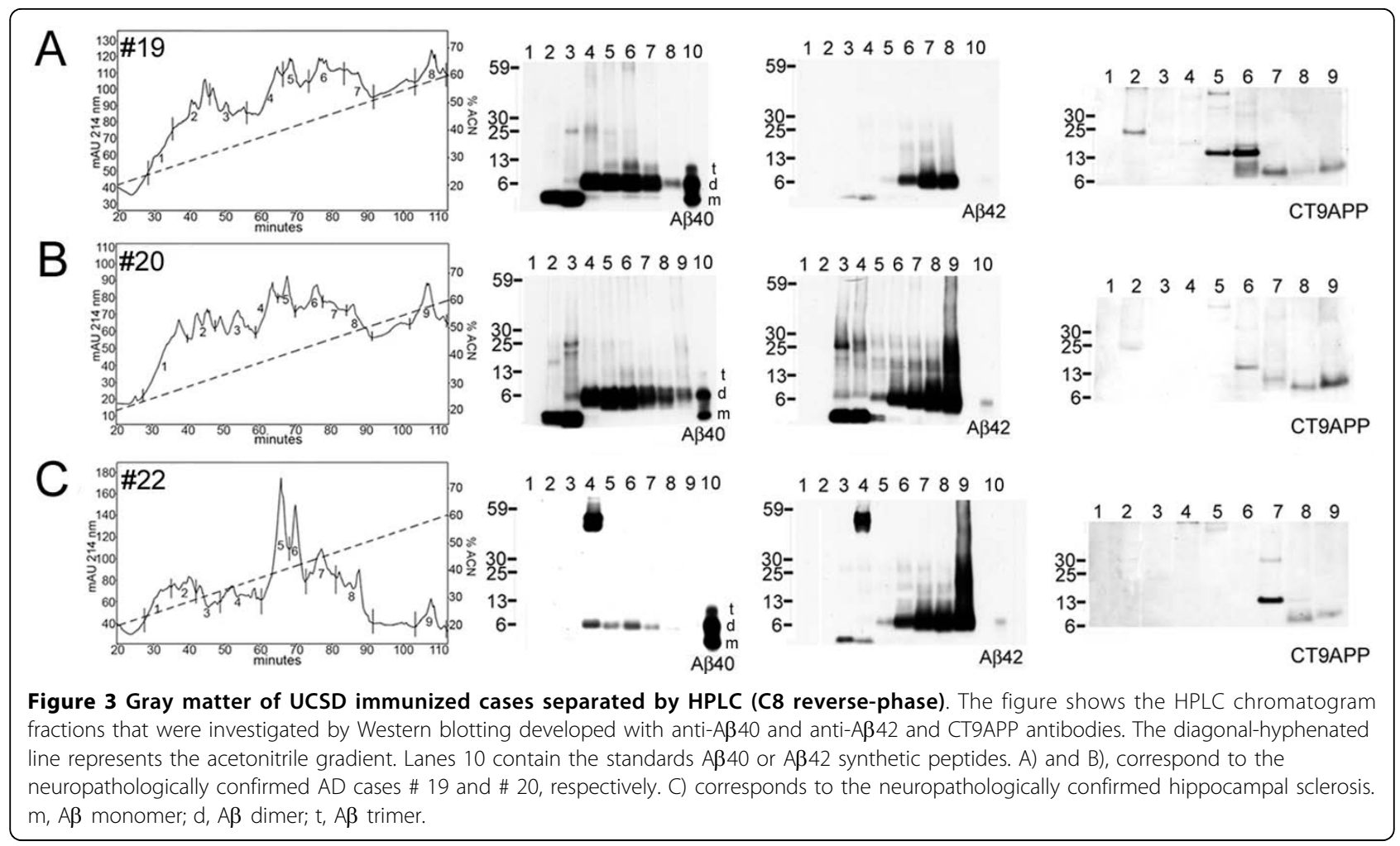

due to the convoluted mixture of peptides that hinders the rate of laser ionization, in AD there is a strong preponderance of dimeric $\mathrm{A} \beta$-related oligomers relative to the number of monomers as suggested by our HPLC/ Western blot studies (see Figure 3) and other studies performed in our laboratory that suggest dimeric $A \beta$ as the most stable and abundant oligomeric association [43-45].

\section{Discussion}

The outcome of active and passive $A \beta$ immunization in APP transgenic mice models and AD patients is consistent with efficient amyloid plaque disruption, although the degree of senile core regression has been highly variable among both the treated rodents and humans. At present, more than $40 \mathrm{~A} \beta$ immunotherapy clinical trials involving about 10,000 subjects are being actively pursued (Alzheimer Research Forum; http://www.alzforum. org/new/detail.asp?id=2409; April 2, 2010). Interestingly, in phase II clinical trials, passive immunotherapy with Bapineuzumab showed no statistical significance in the two primary outcome measures (ADAS-cog and Disability Assessment for Dementia), although post hoc exploratory analyses on a smaller population of completers showed some small therapeutic effects [33,46]. However, it remains to be established whether or not anti-amyloid immunotherapy will lead to a clear improvement in cognition and quality of life enhancement for AD patients or even arrest dementia progression.
The urgent need for trustworthy biomarkers for $\mathrm{AD}$ is well illustrated by the proportion of potentially confounding clinical misdiagnoses discovered in the present study. Two out of the 9 individuals clinically diagnosed with $\mathrm{AD}$ dementia were subsequently recognized

Table 5 SELDI-TOF peptides captured with $A \beta 40$ and $A \beta 42$ antibodies and 6E10

\begin{tabular}{lll}
\hline $\mathbf{M}_{\mathbf{r}}$ Observed & $\mathbf{M}_{\mathbf{r}}$ Calculated & Peptide Sequence \\
\hline 3371.2 & 3373.0 & $17-49(2 \mathrm{f})$ \\
3442.2 & 3444.1 & $17-50(\mathrm{f})$ \\
3486.1 & 3488.1 & $17-50(\mathrm{ox} / 2 \mathrm{f})$ \\
4514.5 & 4514.1 & $1-42$ \\
4925.5 & 4924.7 & $2-47$ \\
4940.7 & 4942.6 & $1-46(\mathrm{ox})$ \\
5371.4 & 5670.8 & $11-62$ \\
6178.3 & 6177.2 & $6-61(3 f)$ \\
6723.3 & 6724.9 & $11-73(\mathrm{ox})$ \\
7178.2 & 7180.3 & $4-68(30 \mathrm{ox})$ \\
8202.0 & 8204.1 & $3 p \mathrm{p}-40+4-40(40 x)$ \\
8411.7 & 8412.3 & $3 p \mathrm{p}-40+2-40(\mathrm{ox} / 2 \mathrm{f})$ \\
8450.4 & 8445.4 & dimer 2-40 (ox) \\
8565.4 & 8563.9 & $5-82$ \\
9265.5 & 9262.4 & dimer 1-43 (2ox) \\
9273.0 & 9273.7 & $17-99(40 x)$ \\
9624.0 & 9623.1 & $11-96(\mathrm{ox})$ \\
\hline
\end{tabular}

f, formyl; ox, oxygen; $\mathrm{pE}$, pyroglutamyl. 
neuropathologically as PSP and HS cases. Interestingly, observations from our own brain bank at BSHRI indicate that only about $50 \%$ of the AD cases should be considered neuropathologically uncomplicated AD [36]. The remainder represents $\mathrm{AD}$ pathology combined with other neurodegenerative disorders, which produce severe cognitive and intellectual deterioration, such as vascular dementia, dementia with Lewy bodies, fronto-temporal dementia, Parkinson's disease, PSP, HS, or dementia without distinctive pathology. In the absence of a reliable clinical diagnosis for $\mathrm{AD}$ and confronted by the near or total absence of amyloid plaques in many autopsied patients who received immunotherapy, it is impossible to be certain that all these individuals actually exhibited AD plaque pathology at the onset of treatment or were at risk of developing this pathology. The introduction of imaging techniques for the detection of amyloid plaque burden such as those based on contrast-producing $A \beta$ binding dye compounds exemplified by Pittsburgh compound-1 ( ${ }^{11} \mathrm{C}$-PiB-PET) will be of assistance in selecting candidates suitable for immunotherapy.

Detailed postmortem examinations of AN-1792 clinical trial participants have been undertaken by our research group and others [24-31]. A critical observation is the wide range of responses to immunotherapy reflected in the extreme variability in $A \beta$ peptide levels among treated individuals as revealed by immunoassay studies. Assuming that the treatment commenced in patients possessing a full complement of amyloid plaques, neuropathological examination consistently demonstrated localized to extensive areas in which senile plaques apparently were disrupted. In addition, ELISA analyses suggest that in some cases the total amount of $A \beta$ was reduced as a consequence of therapy. This inter-patient variability indicates that it will be necessary to personalize treatment regimens and titrate doses precisely to enoptimal efficacy and safety.

Our previous report [28] examined 2 AD cases immunized with the AN-1792 antigen. In one of these cases, the patient received 2 intramuscular doses of $225 \mu \mathrm{g}$ of the immunogen. Nine months after the second immunization the patient developed non-terminal aseptic meningoencephalitis. In the second case, 3 doses of $225 \mu \mathrm{g}$ were administered and the patient died one year after the first immunization as a result of "failure to thrive". Both individuals carried ApoE $\varepsilon 3 / \varepsilon 4$ genotypes. In both cases, postmortem examination revealed that some areas of the brain exhibited near complete apparent amyloid plaque disruption with solubilization, but without $\mathrm{A} \beta$ clearance from the brain. Both vascular and diffuse amyloid deposits resisted AN-1792 disruption. The total amount of $\mathrm{GHCl}$-soluble $\mathrm{A} \beta$ in the patient who developed meningoencephalitis was $868 \mu \mathrm{g} / \mathrm{g}$ wet weight compared to 186 $\mu \mathrm{g} / \mathrm{g}$ wet weight in the second patient. The mean $\mathrm{A} \beta$ values in non-immunized $\mathrm{AD}(\mathrm{n}=31)$ and $\mathrm{NDC}(\mathrm{n}=$ 22) were $406 \mu \mathrm{g} / \mathrm{g}$ wet weight and $221 \mu \mathrm{g} / \mathrm{g}$ wet weight, respectively [28]. However, while overall trends can be equated, these values are not directly comparable to those in the present study because the $A \beta$ extraction technique was different and the scale of the reported means were different as well, being presented in $\mathrm{ng} / \mathrm{mg}$ of total protein versus $\mu \mathrm{g} / \mathrm{g}$ wet weight. As in the present study, total $A \beta$ peptide levels varied widely between the two cases. Tris-soluble $\mathrm{A} \beta$ was 4.5 times higher and GHCl WM A $\beta$ was 5.7 times higher in the meningoencephalitis case when compared to the second case. In the two immunized cases from the previous paper, the levels of Tris-soluble $A \beta$ were increased over the levels in the NDC and non-immunized AD groups [28]. The same trend was repeated in the current study, where the $\mathrm{AD}$ immunized cases (with the exception of case \# 14) had higher levels of Tris-soluble $A \beta$ than in the means of the $\mathrm{AD}$ and NDC populations. In our previous study, there also was an apparent substantial increase in the amount of vascular amyloid deposits as assessed by thioflavine-S staining [28].

The fact that elimination of amyloid plaques did not alter the trajectory of decline into dementia [29] was a disappointment and suggests the disquieting possibility that amyloid plaques alone are not the direct underlying cause of dementia. Several recent studies have demonstrated that after a follow-up of two years, ${ }^{11} \mathrm{C}-\mathrm{PiB}$ uptake remains unchanged in patients with $\mathrm{AD}[47,48]$. However, while amyloid deposits were stable, there was a significant decrease $(\sim 20 \%, p=0.01)$ in regional metabolic rate for glucose [48]. Furthermore, serial ${ }^{11} \mathrm{C}-\mathrm{PiB}-\mathrm{PET}$ and MRI in NDC, mild cognitive impairment (MCI) and AD patients demonstrated that amyloidosis alone is not sufficient to produce cognitive decline which appears to be driven by brain atrophy and neurodegeneration [49]. Interestingly, the volumes of ventricular expansion continue to increase as time progresses in $\mathrm{NDC}(1.3 \mathrm{ml} /$ year$), \mathrm{MCI}(2.5 \mathrm{ml} /$ year $)$ and $\mathrm{AD}(7.7 \mathrm{ml} /$ year), a manifestation of either natural aging or brain pathology-associated atrophy [49]. Amyloid plaques, although undoubtedly noxious, may represent a rescue program for the brain to manage $A \beta$ accumulation [50]. Some studies have suggested that soluble dimeric A $\beta$-species represent the most toxic forms of these molecules [44,51] signifying that an exclusive focus on amyloid plaque remediation is simply too limited.

Notwithstanding disappointment in the fact that disruption of amyloid plaques neither cured dementia nor halted its progression, it is too soon to pronounce this strategy a failure. First and foremost, the hypothesis that amyloid plaques are the prime dementia-causing pathology has not yet been tested rigorously. Biochemical dissection has revealed that amyloid plaques are more than 
accumulated $A \beta$, but actually represent complex multimolecular assemblages [52,53]. Postmortem examinations have revealed that some amyloid plaques are not reversed completely by immunotherapy [28] and remnants, dubbed "collapsed" plaques [25] or "moth-eaten" plaques [27] composed of insoluble molecules persist. It is possible that despite the impressive morphological effects of immunotherapy, "amyloid plaque skeletal remnants" harbor toxic moieties and continue to exert a deleterious legacy effect on dementia development. In addition, the $\mathrm{A} \beta$ spectrum composing plaque deposits may be sufficiently diverse in structure to thwart complete disruption by the immunotherapeutic agents employed to date. The humanized monoclonal antibodies that recognize the $\mathrm{A} \beta$ molecule $\mathrm{N}$-terminus [46] will fail to recognize the terminally-truncated $A \beta$ species demonstrated to be prevalent in human senile plaques [41]. Furthermore, diffuse plaques lack surrounding reactive microglia and fall short of eliciting an inflammatory response $[54,55]$. This phenomenon may be due to the absence of the A $\beta$ HHQK domain that binds to the glycosaminoglycans on the surface of microglia $[13,14]$. Furthermore, diffuse plaques that are mainly composed of P3 (A $\beta$ residues 17-42 [56]), may elude disruption by immunotherapy directed to the $\mathrm{N}$-terminal domain of $A \beta$. The $\alpha$-secretase cleavage does not generate amyloidogenic peptides and therefore it has been considered a favorable therapeutic pathway. However, there is evidence supporting the contention the P3 activates JNK and caspase-8 resulting in neuronal apoptosis [57]. In addition to amyloid and diffuse plaque deposits, AD patients harbor NFT and these lesions have persisted in patients who have received anti-A $\beta$ immunotherapy $[24,25,27,28,31,35]$. Because several distinct classes of pathological and biochemical lesions typically co-exist in AD patients, a complete cure for dementia may simply need to address more than amyloid plaques.

The broad-scale, chronic use of anti-amyloid plaque immunotherapy is complicated by the fact that the fundamental function(s) of the evolutionarily-conserved $A \beta$ molecules remain unknown. One possibility is that amyloid deposits perform a vascular damage rescue function by forming a patch wherever the blood brain barrier (BBB) is breached [17]. Studies in transgenic mice and humans reveal that $A \beta$ immunotherapy exerts powerful, sometimes deleterious effects on vascular integrity and function [30,31,58-60]. In addition, direct clinical experience has confirmed that individuals harboring ApoE\&4 genes are more likely to suffer severe adverse effects from amyloid immunotherapy. While it is unclear whether these responses are a cause or consequence of vascular pathology, they unfortunately do reveal that AN-1792 is contraindicated outright or must be applied with caution in the patient subpopulation known to be most at risk for $\mathrm{AD}$ development.

The enhanced production of TNF- $\alpha$ in the immunized AD cases revealed an ongoing inflammatory reaction in part generated by antigen-antibody interactions. Opsonization of $A \beta$ and subsequent uptake by microglia through the Fc receptors stimulates the secretion of molecules such as interleukin (IL)-1, IL-6, IL-10, TNF- $\alpha$ and macrophage colony stimulating factor that promote neuroinflammation and opening of the BBB. These paradoxical reactions need to be considered in the design of effective immunotherapies [61]. In addition, TNF- $\alpha$ suppresses $A \beta$ degradation by reducing the expression of insulin degrading enzyme [62].

Despite a decade of promising developments in amyloid plaque mitigation, whether the amyloid hypothesis represents the ultimate mechanistic explanation for sporadic AD pathology remains undetermined. Regardless of the role of amyloid plaques as the leading cause for dementia, the existing efforts to combat these lesions need further development. In addition to examining the pathophysiology underlying the remarkable amyloid plaque disruption in the brain following immunotherapy, an account of the role of peripheral pools in increasing levels of circulating $A \beta$ requires a full mechanistic explanation.

\section{Conclusions}

In summary, our results revealed a wide variation in the overall proportions of $A \beta 40$ and $A \beta 42$ peptides among the immunized individuals, with a general predominance of SDS-stable dimeric forms over monomeric ones. In addition, SELDI-TOF MS demonstrated an array of A $\beta$-related peptides, mainly extending towards the $\mathrm{C}$-terminal domain of APP that, in part, may result from the strong extraction conditions that we utilized, capable of totally dispersing membrane structures. Pro-inflammatory TNF- $\alpha$ levels were significantly increased in the GM of immunized AD cases compared to the NDC and nonimmunized AD groups. Amyloid- $\beta$ immunization resulted in amyloid plaque disruption and clearance to widely divergent extents, with levels ranging from below the limit of detection to values exceeding those seen in non-immunized AD cases in ELISA. These idiosyncratic responses, in conjunction with the wide range of biological and pathological variation that characterize aging and disease conditions, will make it difficult to interpret data derived from therapeutic investigations. Moreover, this variation enormously complicates recognition of suitable biomarkers for AD. Our data suggest that the therapeutic outcome will depend on the quality and the quantity of administered immunogens and the patient's immunological responses with the ApoE phenotype appearing to modulate the effectiveness of plaque and vascular amyloid 
removal. In attempting to deploy $A \beta$ antibodies as $A D$ therapeutic tools, the full range of physicochemical properties of the $A \beta$ peptides in humans should be considered. Although in some cases the removal of amyloid plaques by $\mathrm{AN}-1792$ appeared to be impressive, there were no proportionate alterations in the clinical progression of Alzheimer's disease.

\section{List of Abbreviations}

${ }^{11} \mathrm{C}$-PiB: Pittsburgh compound; AB: amyloid-beta; AD: Alzheimer's disease; ApoE: apolipoprotein E; APP: amyloid-beta precursor protein; BBB: blood brain barrier; BSHRI: Banner Sun Health Research Institute; CAA: cerebral amyloid angiopathy; CERAD: Consortium to Establish a Registry for Alzheimer's disease; CHCA: $\alpha$-cyano-4-hydroxycinnamic acid; F: female; f: formyl; FLA: frontal lobe atrophy; FPLC: fast protein liquid chromatography; GDFA: glass distilled formic acid; GHCl: guanidine hydrochloride; GM: gray matter; HPLC: high performance liquid chromatography; HS: hippocampal sclerosis; IL: interleukin; Imm: immunization; M: male; MALDI-TOF: matrixassisted laser desorption/ionization-time of flight; MCl: mild cognitive impairment; MMSE: mini mental state examination; MS: mass spectrometry; n/a: not available; NDC: non-demented control; NFT: neurofibrillary tangles; Non-ADD: non-Alzheimer's disease dementias; NP: neuritic plaque; ox: oxygen; pE: pyroglutamyl; PIC: protease inhibitor cocktail; PS: presenilin; PSP: progressive supranuclear palsy; TFA: trifluoroacetic acid; Tg: transgenic; TNF$\alpha$ : tumor necrosis factor-alpha; USCD: University of California San Diego; USSM: University of Southampton School of Medicine; PBS: phosphate buffered saline; RT: room temperature; SELDI-TOF: surface enhanced laser desorption/ionization-time of flight; WM: white matter; WMR: white matter rarefaction

\section{Declaration of Competing interests}

JARN is a consultant/advisor relating to Alzheimer immunization programs: Elan Pharmaceuticals, GSK, Novartis, Roche, Janssen Alzheimer Immunotherapy Research and Development. MNS receives grant support (clinical trials) from BMS, Avid, GE, Bayer, Baxter, Wyeth, Janssen, Lilly and Medivation. MNS is also on the Consultant/advisory board for Janssen/Pfizer, Amerisciences, Eisai and GSK, and receives royalties from Amerisciences and Wiley. TGB receives funding from AVID-Bayer GE Radiopharmaceuticals. The remaining authors have no competing interests.

\section{Authors' contributions}

MNS and TGB provided the clinical and neuropathological assessments of the $A D$ and NDC individuals. JAN and EM provided clinical and neuropathological data of AN-1792 cases. WMK, RLP, DCL, CLM and IDD were involved in the collection and analysis of the data. AER, TAK and EMC were involved in the design of experiments and final production of the manuscript. All the authors participated in revising and editing of the manuscript.

\section{Acknowledgements}

This study was supported by the National Institute on Aging (NIA) grants: R01 AG-19795, the NIA Arizona Alzheimer's Disease Core Center P30 AG19610 and by grants from the State of Arizona to the Arizona Alzheimer's Research Consortium. We express our gratitude to Dr. Douglas Walker (BSHRI) for performing ApoE genotyping. JARN receives funding from the UK Alzheimer Research Trust. Clive Holmes and Delphine Boche contributed to the clinical and neuropathological assessments of the cases from the University of Southampton School of Medicine.

\section{Author details}

'The Longtine Center for Neurodegenerative Biochemistry, Banner Sun Health Research Institute, Sun City, AZ, USA. ${ }^{2}$ Department of Microbiology, Midwestern University, Glendale, AZ, USA. ${ }^{3}$ Department of Neurosciences, University of California San Diego, La Jolla, CA, USA. ${ }^{4}$ Division of Clinical Neurosciences, University of Southampton School of Medicine, Southampton, UK. ${ }^{5}$ Cleo Roberts Center for Clinical Research, Banner Sun Health Research Institute, Sun City, AZ, USA. ${ }^{6}$ Department of
Neuropathology, Banner Sun Health Research Institute, Sun City, AZ, USA.

${ }^{7}$ Fundacion Instituto Leloir, Buenos Aires, Argentina.

Received: 19 August 2010 Accepted: 7 October 2010

Published: 7 October 2010

\section{References}

1. Brookmeyer R, Johnson E, Ziegler-Graham K, Arrighi HM: Forecasting the global burden of Alzheimer's disease. Alzheimers Dement 2007, 3:186-191

2. 2010 Alzheimer's disease facts and figures. Alzheimers Dement 2010 6:158-194

3. Glenner GG, Wong CW: Alzheimer's disease: initial report of the purification and characterization of a novel cerebrovascular amyloid protein. Biochem Biophys Res Commun 1984, 120:885-890.

4. Masters $\mathrm{CL}$, Simms G, Weinman NA, Multhaup G, McDonald BL, Beyreuther K: Amyloid plaque core protein in Alzheimer disease and Down syndrome. Proc Natl Acad Sci USA 1985, 82:4245-4249.

5. Hardy JA, Higgins GA: Alzheimer's disease: the amyloid cascade hypothesis. Science 1992, 256:184-185.

6. Selkoe DJ: Alzheimer's disease: genes, proteins, and therapy. Physiol Rev 2001, 81:741-766.

7. Joseph J, Shukitt-Hale B, Denisova NA, Martin A, Perry G, Smith MA: Copernicus revisited: amyloid beta in Alzheimer's disease. Neurobiol Aging 2001, 22:131-146.

8. Obrenovich ME, Joseph JA, Atwood CS, Perry G, Smith MA: Amyloid-beta: a (life) preserver for the brain. Neurobiol Aging 2002, 23:1097-1099.

9. Lopez-Toledano MA, Shelanski ML: Neurogenic effect of beta-amyloid peptide in the development of neural stem cells. J Neurosci 2004, 24:5439-5444.

10. Robinson SR, Bishop GM: Abeta as a bioflocculant: implications for the amyloid hypothesis of Alzheimer's disease. Neurobiol Aging 2002, 23:1051-1072.

11. Bishop GM, Robinson SR: The amyloid hypothesis: let sleeping dogmas lie? Neurobiol Aging 2002, 23:1101-1105.

12. Plant LD, Boyle JP, Smith IF, Peers C, Pearson HA: The production of amyloid beta peptide is a critical requirement for the viability of central neurons. J Neurosci 2003, 23:5531-5535.

13. Giulian D, Haverkamp L, Yu JH, Karshin W, Tom D, Li J, et al: Specific domains of beta-amyloid from Alzheimer plaque elicit neuron killing in human microglia. J Neurosci 1996, 16:6021-6037.

14. Giulian D, Haverkamp LJ, Yu J, Karshin W, Tom D, Li J, et al: The HHQK domain of beta-amyloid provides a structural basis for the immunopathology of Alzheimer's disease. J Biol Chem 1998, 273:29719-29726.

15. Thomas T, Thomas G, McLendon C, Sutton T, Mullan M: beta-Amyloidmediated vasoactivity and vascular endothelial damage. Nature 1996, 380:168-171

16. Paris D, Townsend K, Quadros A, Humphrey J, Sun J, Brem S, et al: Inhibition of angiogenesis by Abeta peptides. Angiogenesis 2004, 7: 75-85.

17. Roher AE, Lowenson JD, Clarke S, Woods AS, Cotter RJ, Gowing E, et al: beta-Amyloid-(1-42) is a major component of cerebrovascular amyloid deposits: implications for the pathology of Alzheimer disease. Proc Nat Acad Sci USA 1993, 90:10836-10840.

18. Atwood CS, Bowen RL, Smith MA, Perry G: Cerebrovascular requirement for sealant, anti-coagulant and remodeling molecules that allow for the maintenance of vascular integrity and blood supply. Brain Res Brain Res Rev 2003, 43:164-178

19. Roskam S, Neff F, Schwarting R, Bacher M, Dodel R: APP transgenic mice: the effect of active and passive immunotherapy in cognitive tasks. Neurosci Biobehav Rev 2010, 34:487-499.

20. Loerch PM, Lu T, Dakin KA, Vann JM, Isaacs A, Geula C, et al: Evolution of the aging brain transcriptome and synaptic regulation. PLOS One 2008, 3: e3329.

21. Roher AE, Kokjohn TA: Appraisal of AbetaPP Transgenic Mice as Models for Alzheimer's Disease Amyloid Cascade. Curr Med Chem Immun Endo \& Metab Agents 2003, 3:85-90

22. Kokjohn TA, Roher AE: Amyloid precursor protein transgenic mouse models and Alzheimer's disease: understanding the paradigms, limitations, and contributions. Alzheimers Dement 2009, 5:340-347. 
23. Kokjohn TA, Roher AE: Antibody responses, amyloid-beta peptide remnants and clinical effects of AN-1792 immunization in patients with AD in an interrupted trial. CNS Neurol Disord Drug Targets 2009, 8:88-97.

24. Nicoll JA, Wilkinson D, Holmes C, Steart P, Markham H, Weller RO: Neuropathology of human Alzheimer disease after immunization with amyloid-beta peptide: a case report. Nat Med 2003, 9:448-452.

25. Ferrer I, Boada RM, Sanchez Guerra ML, Rey MJ, Costa-Jussa F: Neuropathology and pathogenesis of encephalitis following amyloidbeta immunization in Alzheimer's disease. Brain Pathol 2004, 14:11-20.

26. Masliah E, Hansen L, Adame A, Crews L, Bard F, Lee C, et al: Abeta vaccination effects on plaque pathology in the absence of encephalitis in Alzheimer disease. Neurology 2005, 64:129-131.

27. Nicoll JA, Barton E, Boche D, Neal JW, Ferrer I, Thompson P, et al: Abeta species removal after abeta42 immunization. $J$ Neuropathol Exp Neurol 2006, 65:1040-1048.

28. Patton RL, Kalback WM, Esh CL, Kokjohn TA, Van Vickle GD, Luehrs DC, et al: Amyloid-beta peptide remnants in AN-1792-immunized Alzheimer's disease patients: a biochemical analysis. Am J Pathol 2006, 169:1048-1063.

29. Holmes C, Boche D, Wilkinson D, Yadegarfar G, Hopkins V, Bayer A, et al: Long-term effects of Abeta42 immunisation in Alzheimer's disease: follow-up of a randomised, placebo-controlled phase I trial. Lancet 2008, 372:216-223.

30. Boche D, Zotova E, Weller RO, Love S, Neal JW, Pickering RM, et al: Consequence of Abeta immunization on the vasculature of human Alzheimer's disease brain. Brain 2008, 131:3299-3310.

31. Uro-Coste E, Russano de PG, Guilbeau-Frugier C, Sastre N, Ousset PJ, da Silva NA, et al: Cerebral amyloid angiopathy and microhemorrhages after amyloid beta vaccination: case report and brief review. Clin Neuropathol 2010, 29:209-216.

32. Orgogozo JM, Gilman S, Dartigues JF, Laurent B, Puel M, Kirby LC, et al: Subacute meningoencephalitis in a subset of patients with $A D$ after Abeta42 immunization. Neurology 2003, 61:46-54

33. Salloway S, Sperling R, Gilman S, Fox NC, Blennow K, Raskind M, et al: A phase 2 multiple ascending dose trial of bapineuzumab in mild to moderate Alzheimer disease. Neurology 2009, 73:2061-2070.

34. Serrano-Pozo A, William CM, Ferrer I, Uro-Coste E, Delisle MB, Maurage CA et al: Beneficial effect of human anti-amyloid-beta active immunization on neurite morphology and tau pathology. Brain 2010, 133:1312-1327.

35. Boche D, Donald J, Love S, Harris S, Neal JW, Holmes C, et al: Reduction of aggregated Tau in neuronal processes but not in the cell bodies after Abeta42 immunisation in Alzheimer's disease. Acta Neuropathol 2010, 120:13-20.

36. Beach $T G$, Sue LI, Walker DG, Roher $A E$, Lue $L$, Vedders $L$, et al: The Sun Health Research Institute Brain Donation Program: description and experience, 1987-2007. Cell Tissue Bank 2008, 9:229-245.

37. Mulugeta E, Molina-Holgado F, Elliott MS, Hortobagyi T, Perry R, Kalaria RN, et al: Inflammatory mediators in the frontal lobe of patients with mixed and vascular dementia. Dement Geriatr Cogn Disord 2008, 25:278-286.

38. Maarouf $\mathrm{CL}$, Daugs ID, Spina $\mathrm{S}$, Vidal R, Kokjohn TA, Patton RL, et al: Histopathological and molecular heterogeneity among individuals with dementia associated with Presenilin mutations. Mol Neurodegener 2008, 3:20.

39. Esh C, Patton L, Kalback W, Kokjohn TA, Lopez J, Brune D, et al: Altered APP processing in PDAPP (Val717 -> Phe) transgenic mice yields extended-length Abeta peptides. Biochemistry 2005, 44:13807-13819.

40. Dean RB, Dixon WJ: Simplified statistics for small numbers of observations. Anal Chem 1951, 23:636-638.

41. Roher AE, Lowenson JD, Clarke S, Wolkow C, Wang R, Cotter RJ, et al: Structural alterations in the peptide backbone of beta-amyloid core protein may account for its deposition and stability in Alzheimer's disease. J Biol Chem 1993, 268:3072-3083.

42. Kuo YM, Emmerling MR, Woods AS, Cotter RJ, Roher AE: Isolation, chemical characterization, and quantitation of A beta 3-pyroglutamyl peptide from neuritic plaques and vascular amyloid deposits. Biochem Biophys Res Commun 1997, 237:188-191.

43. Kuo YM, Emmerling MR, Vigo-Pelfrey C, Kasunic TC, Kirkpatrick JB, Murdoch $\mathrm{GH}$, et al: Water-soluble Abeta (N-40, N-42) oligomers in normal and Alzheimer disease brains. J Biol Chem 1996, 271:4077-4081.

44. Roher AE, Chaney MO, Kuo YM, Webster SD, Stine WB, Haverkamp L, et al: Morphology and toxicity of Abeta-(1-42) dimer derived from neuritic and vascular amyloid deposits of Alzheimer's disease. J Biol Chem 1996, 271:20631-20635.

45. Kuo YM, Webster S, Emmerling MR, De LN, Roher AE: Irreversible dimerization/tetramerization and post-translational modifications inhibit proteolytic degradation of A beta peptides of Alzheimer's disease. Biochim Biophys Acta 1998, 1406:291-298.

46. Kerchner GA, Boxer AL: Bapineuzumab. Expert Opin Biol Ther 2010, 10:1121-1130.

47. Scheinin NM, Aalto S, Koikkalainen J, Lotjonen J, Karrasch M, Kemppainen N et al: Follow-up of [11C]PIB uptake and brain volume in patients with Alzheimer disease and controls. Neurology 2009, 73:1186-1192.

48. Engler H, Forsberg A, Almkvist O, Blomquist G, Larsson E, Savitcheva I, et al: Two-year follow-up of amyloid deposition in patients with Alzheimer's disease. Brain 2006, 129:2856-2866.

49. Jack CR Jr, Lowe VJ, Weigand SD, Wiste HJ, Senjem ML, Knopman DS, et al: Serial PIB and MRI in normal, mild cognitive impairment and Alzheimer's disease: implications for sequence of pathological events in Alzheimer's disease. Brain 2009, 132:1355-1365.

50. Heininger K: A unifying hypothesis of Alzheimer's disease. IV. Causation and sequence of events. Rev Neurosci 2000, 11 Spec No: 213-328.

51. Shankar GM, Li S, Mehta TH, Garcia-Munoz A, Shepardson NE, Smith I, et al: Amyloid-beta protein dimers isolated directly from Alzheimer's brains impair synaptic plasticity and memory. Nat Med 2008, 14:837-842.

52. Liao L, Cheng D, Wang J, Duong DM, Losik TG, Gearing M, et al: Proteomic characterization of postmortem amyloid plaques isolated by laser capture microdissection. J Biol Chem 2004, 279:37061-37068.

53. Roher AE, Palmer KC, Yurewicz EC, Ball MJ, Greenberg BD: Morphological and biochemical analyses of amyloid plaque core proteins purified from Alzheimer disease brain tissue. J Neurochem 1993, 61:1916-1926.

54. Wisniewski HM, Wegiel J: The neuropathology of Alzheimer's disease. Neuroimaging Clin N Am 1995, 5:45-57.

55. Mrak RE: Neuropathology and the neuroinflammation idea. J Alzheimers Dis 2009, 18:473-481

56. Gowing E, Roher AE, Woods AS, Cotter RJ, Chaney M, Little SP, et al: Chemical characterization of $A$ beta 17-42 peptide, a component of diffuse amyloid deposits of Alzheimer disease. J Biol Chem 1994, 269:10987-10990.

57. Wei W, Norton DD, Wang X, Kusiak JW: Abeta 17-42 in Alzheimer's disease activates JNK and caspase-8 leading to neuronal apoptosis. Brain 2002, 125:2036-2043.

58. Racke MM, Boone LI, Hepburn DL, Parsadainian M, Bryan MT, Ness DK, et al: Exacerbation of cerebral amyloid angiopathy-associated microhemorrhage in amyloid precursor protein transgenic mice by immunotherapy is dependent on antibody recognition of deposited forms of amyloid beta. J Neurosci 2005, 25:629-636.

59. Wilcock DM, Colton CA: Immunotherapy, vascular pathology, and microhemorrhages in transgenic mice. CNS Neurol Disord Drug Targets 2009, 8:50-64

60. Burbach GJ, Vlachos A, Ghebremedhin E, Del Turco D, Coomaraswamy J, Staufenbiel M, et al: Vessel ultrastructure in APP23 transgenic mice after passive anti-Abeta immunotherapy and subsequent intracerebral hemorrhage. Neurobiol Aging 2007, 28:202-212.

61. Lue LF, Walker DG: Modeling Alzheimer's disease immune therapy mechanisms: interactions of human postmortem microglia with antibody-opsonized amyloid beta peptide. J Neurosci Res 2002, 70:599-610.

62. Yamamoto M, Kiyota T, Walsh SM, Liu J, Kipnis J, Ikezu T: Cytokinemediated inhibition of fibrillar amyloid-beta peptide degradation by human mononuclear phagocytes. J Immunol 2008, 181:3877-3886.

63. Blessed $\mathrm{G}$, Tomlinson BE, Roth M: The association between quantitative measures of dementia and of senile change in the cerebral grey matter of elderly subjects. Br J Psychiatry 1968, 114:797-811.

doi:10.1186/1750-1326-5-39

Cite this article as: Maarouf et al:: The biochemical aftermath of antiamyloid immunotherapy. Molecular Neurodegeneration 2010 5:39. 